\title{
Artificial receptors for artificial olfaction
}

\author{
C Di Natale \\ From 1st International Workshop on Odor Spaces \\ Hannover, Germany. 4-7 September 2013
}

Any attempt to mimic the behavior of natural olfaction is mainly based on the properties of the artificial sensor units. Since the beginning of artificial olfaction, the main requirement for sensors has been the partial crossselectivity. This trivial feature makes possible the application of the combinatorial selectivity principle to the arrays of gas sensors. The principle of cross-selectivity can actually be fulfilled by almost any kind of sensor technology. This resulted in a vast popularity of "electronic noses" and their application. However, it is important to consider the kind of the cross-selectivity offered by sensors technology. Current sensors combines together the capability of chemistry to synthesize molecules endowed with molecular recognition properties and a number of solid-state devices that actually measure the changes in some physical properties consequent to the chemical interaction event.

From this point of view, it is important to consider that in practice a number of unwanted interaction can take place even if the receptor is designed to emphasize the selectivity towards a particular kind of molecule. These are mainly driven by Van der Waals forces. Most of the available transducers cannot discriminate interactions by their energy and since Van der Waals interactions are rather ubiquitous the sensors tend to be highly correlated. A scrutiny of literature on electronic noses shows that even in case of large arrays, PCA often is limited to two variables.

In this presentation, these principles will be discussed considering the study case of metalloporphyrins. These are a rather versatile class of molecules whose gas sensing properties are actively exploited in Nature, for instance for the transport of molecules such as $\mathrm{O} 2$ and $\mathrm{N} 2$ in blood. The possibility to reduce the influence of common interactions will be illustrated. It has also to be considered that the reduction of correlation is necessary to increase the array size in artificial olfaction systems.

Dept. Electronic Engineering, University of Rome Tor Vergata, Rome, Italy
Published: 16 April 2014

doi:10.1186/2044-7248-3-S1-K6

Cite this article as: Di Natale: Artificial receptors for artificial olfaction.

Flavour 2014 3(Suppl 1):K6.
Submit your next manuscript to BioMed Central and take full advantage of:

- Convenient online submission

- Thorough peer review

- No space constraints or color figure charges

- Immediate publication on acceptance

- Inclusion in PubMed, CAS, Scopus and Google Scholar

- Research which is freely available for redistribution
() Biomed Central 